\section{$\$$ Research Square}

Preprints are preliminary reports that have not undergone peer review.

They should not be considered conclusive, used to inform clinical practice, or referenced by the media as validated information.

\title{
Improving Antibacterial and Anti-biofilmic properties of urological catheters with Eucalyptus, Rosemary, Green tea and Ziziphora extracts by impregnation method
}

Najme Akhlaghi-Ardekani

University of Sistan and Baluchistan Faculty of Engineering

Davod Mohebbi-Kalhori ( $\sim$ akhlaghi.ardekani@gmail.com )

University of Sistan and Baluchistan Faculty of Engineering https://orcid.org/0000-0003-3720-9134

Abdolreza samimi

University of Sistan and Baluchistan Faculty of Engineering

Reza Karazhyan

Institute of Food Science and Technology

\section{Research Article}

Keywords: Herbal extract, antibacterial agent, urinary tract infection, bacteria, Foley catheters

Posted Date: March 10th, 2021

DOI: https://doi.org/10.21203/rs.3.rs-280764/v1

License: (1) This work is licensed under a Creative Commons Attribution 4.0 International License. Read Full License 


\section{Abstract}

The main complications of urinary catheters are the bacteria's biofilm formation and the urinary tract infection caused by gram-positive and gram-negative bacteria. In the recent years, the attention has changed its direction toward the antimicrobial, anti-biofilmic, and hydrophobicity effects of herbal extracts. Some of these extracts can inhibit the colonization of the two bacteria Staphylococcus aureus and Escherichia coli which are resistant to antibiotics. These bacteria can stick to the surface of polymer materials due to their hydrophobicity. Thus, antibacterial hydrophilic herbal extracts are supposed to help reduce the risk of the surficial infection if they are used to impregnate the urinary catheters. In this research, the extracts of these four plants eucalyptus, rosemary, green tea and ziziphora were used as the antibacterial agents. After the impregnation and modification of the sample catheters, they were tested by AFM, FE-SEM, ATR-FTIR methods to measure their mechanical, chemical, and hydrophilic properties, during the 21-day experiment period, compared to non-impregnated ones. The tests showed the silicone catheters impregnated by the herbal extracts have some significant anti-biofilmic and antibacterial properties $(\mathrm{P} \otimes 0.0001)$ due to the increase in their hydrophilic property. The impregnated catheters could be release the extracts and killed bacteria in 21 days Therefore; some herbal extracts can be good alternatives to chemical drugs.

\section{Introduction}

One of the most important problems which imposes heavy costs on health systems is of the past and present centuries that can be refer to hospital infection, which imposing heavy costs on health system, which can leading to a longer hospitalization period and an causing more increased mortality rate[1]. Therefore, it is critical to investigate cope with the factors associated with the prevalence of hospital infection and find ways to prevent them it. The most prevalent nosocomial infection of this kind is the urinary tract infection, ordinarily caused by a urinary catheter. Usually, chemical antibiotics are $T$ the most well-known important weapons in fighting bacterial infection are antibiotic. But however, over the past few decades, because of these antibiotics weapons were discovered to cause toxic reactions beside the resistance of and bacteria are resistant to them. Besides, On the other hand, the bacteria can attach to surfaces and form organize the biofilms[2]. Nevertheless, it is important to peruse novel drugs to which bacteria are less few bacteria's resistant, such as. The drugs which taken from a natural source which and have significant action impactions in the presentation and the treatment therapy of human diseases[3]. Of course, the herbal extracts have anti-biofilmic properties[4]. The anti-biofilmic is developed by that act of the molecule capability which destroys the biofilm formation process through antibacterial effects (bacteriostatic and bactericidal active), preventing cell adhesion to on surfaces, and inhibiting QS signals[5]. Ordinarily, infection diseases are caused by Escherichia coli, Candida albinos, Pseudomonas aeruginosa and Staphylococcus aureus because of which. And about 50,000 people die in the world per day because of these bacteria[6]. The first step for the in developing the urinary tract infection to be developed is the adherence of planktonic bacteria to the surface of the catheters; , on the other hand however, due to the formation of an exopolymer layer, eliminating a formed of biofilm is more difficult than eliminating the planktonic bacteria , because of the formation of an exopolymer layer[7]. Consequently, by changing the biomaterial properties of the catheters, it is possible to prevent the adherence of bacteria to their surface of the catheters[8]. Usually ordinarily, due to because of the flexibility, low toxicity and physiological property enervation of the silicone rubber, it is being extensively used as the catheter materials to build catheters. Ordinarily however, bacteria tend to easily adhere to this material because of its hydrophobic surface and cause infection [9-10]. The main bacteria that cause the urinary tract infections are Escherichia coli (Gramnegative) and Staphylococcus aureus (Gram-positive)[11], and from two strains both of which strain are have hydrophobic properties[12].

Nevertheless, around the world, the antibacterial properties of plants have been reported around the world[6]. One of the important compounds in herbal extracts is the phenolic compound that destroys they act disrupting the bacteria's cell wall, intervene sing with ATP pool and changeling its membrane potential leading to causing the bacterium's death[13]. The Antibacterial properties of the phenolic compounds are more efficient than those of the non-phenolic compounds because of the hydroxyl group, and aromatic rings[14]. Ordinarily, the water-ethanol (70\%) solvent can have been extracted the maximum amount of the phenolic compounds[15]. The cell membrane and the target interconnection have been the main focused of the extract's' antimicrobial mechanisms[16].

In this study, instead of chemical antibiotics, the silicone Foley catheters have been impregnated by antibacterial herbal agents such as the green tea extract (GTE), the ziziphora extract (ZIE), the eucalyptus extract (EUE) and the rosemary extract (ROE) instead of chemical antibiotics to decrease the catheters' hydrophobicity and improve their antibacterial and anti-biofilmic properties of silicone Foley catheters by herbal extracts-impregnated.

Most of the polyphenols in the green tea leaves (Camellia Sinensis) are catechins and the major one is (-) - epigallocatechin[17]. Thymol and carvacrol have been the phenolic compound of ziziphora cliniopodioes (lamiaceae family)[18]. Rosemary is an herbaceous plant with green aromatic sharp leaves with antimicrobial and antioxidant properties. The most important active ingredient in the rosemary extract

Page 2/19 
(ROE) is cornosol. The other phenolic compounds are rosemanol, isorosemanol, rosmarinic acid[19]. Eucalyptus is one of the most famous herbs having antimicrobial effects. Accordingly, this plant is a rich source of polyphenols. ; Nevertheless, the main compound of the eucalyptus extract its main compounds include is 1.8-cineol (eucalyptol)[20].

In this study, a solvent was utilized to dissolve the herbal extracts without a considerable chemical change in them. Next, utilizes a swelling agent was also added to the solvent which is capable of to increase enhance the intermolecular space of silicone catheters and which is capable of dissolving herbal extracts without substantially chemically change them under situation and in a method way to permit the infusion of herbal extracts into the swelled silicone substantially uniformly as much as possible. This process to provide for an extended significant level of antibacterial and anti-biofilmic effect when the infused silicone is subsequently catheters in the body[21].

In this method, the silicone catheter properties were having been improved in order to and prevented the adhesion of the bacteria on to the surface. Moreover, the planktonic bacteria living in the bladder were inhibited by the polyphenol compounds that had been released from the catheters. The roughness of the catheters' surfaces and the mechanical properties of the catheters were examined, as well $b$ before and after the modification, had been examined as well.

\section{Materials And Methods}

\section{Extraction}

The ziziphora, green tea, eucalyptus and rosemary were provided by the Plant Science Institute. The herbal extracts were taken by using the maceration method [22]. The ziziphora, green tea, eucalyptus and rosemary were provided by the Plant Science Institute In this method,. $T$ the dried plant's leaves of the mentioned plants $(10 \mathrm{gr})$ were separately milled and, then, the powdered leaves were added to $70 \%$ ethanol (C2H60) $(100 \mathrm{ml})$ and remained on the shaker for 24 hours and were finally filtered using a cellulose filter paper $(0.45 \mu \mathrm{m})$. The four different extractions were then concentrated by, using a vacuum rotary evaporator (Heidolph, Germany). The extracts were next placed in an oven to be dried (Binder, USA), and then the dried extracts were shaved. The antibacterial effect of the extractions was has also been tested[22].

\section{Impregnation process}

In this study, we applied the impregnation method as illustrated by has been used in this study (Fig.1). Firstly, UV was used for sterilization of the samples of Foley silicone catheters (MPI, Germany) were exposed to UV for 30 minutes in order to be sterilized. The anti-bacterial extracts were as separately dissolved in a $70 \%$ ethanol solution to which the $(70 \%)$ and added to chloroform (Carolart, Italy) solution was added as a penetration agent to prepare a concentration of 100, 200 and $300 \mathrm{mg} / \mathrm{ml}$ for each plant's extract. Then, the strips of the silicone Foley catheter which were cut into $(11 \mathrm{~cm}$ longength) pieces were immersed in the solutions for an hour, and during which this time, the catheter pieces was swelleden to almost twice its their original size. The samples were then removed and washed with ethanol $(70 \%)$ to remove residual solvents and extracts. They were then placed atin the room temperature against the air flow to dry overnight to dry[23]. After the solvent evaporated, the size of the catheter pieces size returned to theirits original state. Consequently, as indicated by the color of the catheters, accordingly, the antibacterial agent attempted to protruded from the polymer; consequently, it and got spreaded in the polymer's matrix equally.

\section{Microbial test}

\section{Zone of inhibition}

A direct contact method (Kirby-Bauer) washas been used to evaluate the antibacterial properties of the non-impregnated catheter and impregnated catheter samples. In this method, the zones of inhibition were defined for of the two major main infection-causing bacteria (Escherichia coli (ATCC 25922) and Staphylococcus aureus (ATCC 25923)) have been defined. The bacterial suspensions were prepared by, using the purified bacteria in the nutrient broth (N.B, Merck, Germany) at $37^{\circ} \mathrm{C}$ and at the concentration of $0.5 \mathrm{McFarland}$ $(1 \times 108 \mathrm{cfu} / \mathrm{ml})$ and then, we diluted the suspensions with ringer (Merck, Germany) and braughting it to $1 \times 10^{6}$ (CFU/ml). Next, Ta cotton swab which was inserted into the suspension was and rubbed on the surface of the nutrient agar plates. As two separate groups, The NON-IMC and IMC samples were placed on the surface of the prepared a nutrient agar plates. And were Then each bacterial sample was 


\section{The Durability effect of the impregnated ion catheters (Broth diffusion test)}

The no impregnated catheters and impregnated samples were also examined using a quantitative dilation method. In the dilation method, $57 \mathrm{cc}$ of each of the two samples bacterial the suspensions $\left(1 \times 10^{6} \mathrm{CFU} / \mathrm{ml}\right)$ from each sample is was separately added separately to two test tubes each containing $4 \mathrm{cc}$ of the nutrient broth medium. Then, , and the sterilized fragments of IMC were placed inside one of the test tubes and sterilized the sterile NON-IMC fragments were e placed put inside the other one test tube individually; next and then , the two test tubes were placed into within the incubator at $37^{\circ} \mathrm{C}$; at last, . the test tubes Polymer-containing containers are were repeatedly taken out removed from the incubator on $\mathrm{r}$ in the $1 \mathrm{st}, 3 \mathrm{rd}, 7 \mathrm{th}$, and 14 th first days of the incubation to counts; afterward, the number of the grown colonies is counted by using the a colony counter. Considering the probability factor, there is may be an error in microbial tests. To increase the accuracy of the data, the microbial tests were done three times for each sample, and the averages of the test results were considered as the test data[25].

\section{Chemical properties}

\section{Attenuated Total Reflectance Fourier Transforms Infrared (ATR-FTIR) spectroscopy}

To demonstrate the chemical structure of the surface of the sample catheters EUE-IMC, and ROE-IMC (100 mg/ml), and nonimpregnated catheters, we used an ATR-FTIR spectroscope (Avatara 370 FT-IR Thermo Nicolet made in USA) within the spectral range of 500 to $4000(\mathrm{~cm} \mathrm{-1)}$ has been utilized[26].

\section{Physical properties}

\section{The surface properties of catheters (Contact angle measurement)}

The surface hydrophobicity of the EUE-IMC, ROE-IMC , EUE-IMC and ROE-IMC (100 mg/ml) and non-impregnated surface catheters was recorded studied by measuring the water contact angle. The contact angle of with water droplets $(2.5 \mu \mathrm{l})$ was measured by the Dino Light's AM-7013MZT digital microscope with 40x magnification. Moreover, Image software was used to measure the contact angle of the droplets at the desired level. This process, as it was repeated three times[27].

\section{Atomic Force Microscopy Analysis (AFM)}

Increasing the High surface roughness may lead to the catheter outburst or physical injury of patients. That's why For that reason, we analyzed the surface of NON-IMC, EUE-IMC and GTE-IMC $(100 \mathrm{mg} / \mathrm{ml})$ catheters which were cut into that were $1 \mathrm{~cm}$ long pieces apart from each other and coated with the extract by were placing them inside a phosphate buffer saline (P.B.S) at room temperature for a month, while we replaced the saline once every 3 days with a new P.B.S. At the end of the examination, the catheters were removed and analyzed with an AFM[28].

\section{Field Emission Electron Microscope and Energy Dispersive Using X-Ray (Fe- SEM)}

In order to show that the effects of the plants extracts on the bacterial adhesion and the biofilm formation of bacteria, we needed to fixate some living bacteria on the surfaces of all sample catheters i. e. The EUE-IMC, ROE-IMC, GTE-IMC and ZIE-IMC ( $100 \mathrm{mg} / \mathrm{ml})$ and nonimpregnated catheters; after bacteria fixation, we put the samples for 2 hours in the $25 \%$ glutaraldehyde in P.B.S. Next, the fixed bacteria 
were dehydrated by being placed for 10 minutes in each of different graded ethanol solutions $(25 \%, 50 \%, 75 \%, 95 \%$ and $100 \%)$. Then, the samples were coated by platinum[9]. And, they were photographed using a Field Emission Scanning Electron Microscope (FE-SEM)[29].

\section{Mechanical properties}

It is so significant that the physical and mechanical properties of catheters should not change after the modification process. ce, which has been no damage, occurs on catheters and physical properties not change after the modifying. Furthermore however, catheters are exposed to tensile force while being operated and removed. Thus, in this study, we found it necessary to measure the catheters' tensile stress and modulus at the break. Accordingly, the control and experimental samples of the catheters (EUE-IMC, ROE-IMC, EUE-IMC, ZIE-IMC $100 \mathrm{mg} / \mathrm{ml} \&$ non-impregnated) were cut into $4 \mathrm{~cm}$ long pieces to get exposed to tensile testing by $2 \mathrm{KN}$ force at the speed of 300 $\mathrm{mm} / \mathrm{min}$. These pieces were exposed to testing for the second time after one month of being in the PBS solution (the PBS was renewed every three days) (Instron 5985)[28]

\section{Data analysis}

In this research, Graph Pad Prism 8.0.1 software was used to do the required statistical analysis. The reported data are the recorded mean outcomes ( $\log _{-} 10[\mathrm{CFU} / \mathrm{ml})$. The two-way variance analysis (ANOVA) was also used to compare the colonization between the catheter sample groups (IMC (Control-catheter), non-imprignated and Control-bacteria) during a 21 -day period by a $95 \%$ confidence interval. The ANOVA was conjuncted with Tokey's post hoc test for the all sample's analysis. The results were considered statistically significant at $p<0.05$ level.

\section{Results And Discussion}

The catheters (Fig. 2) Impregnated by the EUE ( with the concentration of 25, 50, 100, 200 and $300 \mathrm{mg} / \mathrm{ml}$ ), the ROE (with the concentration of 100,200 and $300 \mathrm{mg} / \mathrm{ml}$ ), the GTE (with the concentration of $50,100,200$ and $300 \mathrm{mg} / \mathrm{ml}$ ) and the ZIE (with the concentration of 50, 100 and 200, mg/ml) were tested on the nutrient agar encoutering Staphylococcus aureus and Escherichia coli (both $1 \times 10^{6} \mathrm{CFU} / \mathrm{ml}$ ); the zone of inhibition is shown in Fig. 3 and Table 1. The number of bacteria grown by the dilution method on the different agar nutrients (N.A, Merk US) related to the impregnated catheters and no impregnated catheters sample groups were obtained on the 1st, 3rd, 7th, 14th, and 21st days of the experiment and are illustrated by Fig. 4 and 5. The Graph Pad Prism 8.0.1 software was used to analyze and calculate and the data's mean \pm SD.

Table 1 The diameter of the inhibition zone of two plants in two strain bacteria

\begin{tabular}{|c|c|c|c|c|c|c|}
\hline \multicolumn{2}{|c|}{ Type ofBacterial Isolates } & \multicolumn{5}{|c|}{ Concentration of extract $(\mathrm{mg} / \mathrm{ml})$} \\
\hline & $\left(1 \times 10^{6} \mathrm{cfu} / \mathrm{ml}\right)$ & 25 & 50 & 100 & 200 & 300 \\
\hline & & \multicolumn{5}{|c|}{ Clean zone diameter $(\mathrm{mm})$} \\
\hline ROE-IMC & S. aureus & - & - & 23 & 23 & 24 \\
\hline -IMCEUE & & 15 & 15 & 22 & 24 & 25 \\
\hline GTE-IMC & & - & - & - & - & - \\
\hline ZIE-IMC & & - & - & - & - & - \\
\hline ROE-IMC & E. coli & - & - & 22 & 24 & 32 \\
\hline -IMCEUE & & 20 & 20 & 24 & 25 & 34 \\
\hline GTE-IMC & & - & - & - & - & - \\
\hline ZIE-IMC & & - & - & - & - & - \\
\hline
\end{tabular}

(-) No clean zone diameter

As shown in the Fig. 3, 4 and 5 and Table 2, 3, 4 and 5, after the comparison of the effects the two bacteria on the different concentrations of EUE-IMC samples during the experiment period, it was observed that the $100 \mathrm{mg} / \mathrm{ml}$ EUE-IMC sample could not have the bactericidal effect after 24 hours; however, their growth was prevented. Conversely, the tests on the 3rd, 7th, 14th, and 21st days showed that the $100 \mathrm{mg} / \mathrm{ml}$ EUE-IMC sample could extinguish the bacteria (no colonies observed on the plate). The tests also showed that the 200 and $300 \mathrm{mg} / \mathrm{ml}$ concenterated EUE-IMC samples and all the concentrations of ROE-IMC (100, $200 \mathrm{and} 300 \mathrm{mg} / \mathrm{ml})$ could extinguish the bacteria on the different test days. As observerd in the experiment, as the concentration of the herbal extracts went higher, their antibacterial effects increased, too. The EUE-IMC sample was more effective than the ROE-IMC sample in preventing E. Coli. compared with S. Aureus. So, EUE-IMC yielded better results, compared to that of the ROE-IMC. The figures 4 and 5 and the tables 2, 3, 4 and 5 indicates that the obtained results are significantly close to the mean but they show some dispersion. The different concentrations of EUEIMC showed a significant antibacterial effect $(p<0.0001)$ on the bacteria which is consistent with the results of Bhalodia et al[ $[3]$ Also, the 
ROE-IMC samples showed the same results $(P<0.0001)$. According to the figures 4 and 5 , while being in the body, the extractions penetrated into the samples GTE-IMC (P®0.0001) and ZIE-IMC (p凶0.0001) released and eliminated the bacteria, while the obtained results of the GTE-IMC $(100 \mathrm{mg} / \mathrm{ml})$ and GTE-IMC $(200 \mathrm{mg} / \mathrm{ml})$ were not significant. As a result, the modified IMC samples can extinguish the bacteria over time compared to the NON-IMC control samples. The number of bacteria on the control samples of catheters increased day by day during the experiment.

The green tea extract has natural aromatic polyphenol compounds such as catchiness that include hydroxyl[30]. A small amount of green tea extract was used in the impregnation step of this experiment. The hydroxyl monoterpenes of ziziphora compounds are carvacerol and thymol which were the main factor of antimicrobial activity. These ingredients are non-polar phenolic compounds which are in the ziziphora extract and they are slightly solvable in water[18]. The effectiveness of the non-phenolic compounds depends on the type of the alkyl group; the alkenyl, however, is more active than alkyl[31]. The hydroxyl groups $(-\mathrm{OH})$ are active compounds having high antibacterial effects which alkenyl (- $\mathrm{CH}=\mathrm{CH}-)$ increases their efficiency compared to alkyl $(-\mathrm{C}=\mathrm{C}-)$ [32].

Table 2 The mean \pm SD of the number of colonies formed with E.coli on EUE-IMC, ROE-IMC, Control-Catheter, and Control-Bacteria in 21 days

\begin{tabular}{|c|c|c|c|c|c|c|c|c|c|}
\hline \multicolumn{10}{|c|}{ Colonization of E.coli (CFU/ml) } \\
\hline \multirow[b]{2}{*}{ Day } & \multicolumn{5}{|c|}{ EUE-IMC (concentration $\mathrm{mg} / \mathrm{ml}$ ) } & \multicolumn{4}{|c|}{ ROE-IMC (concentration $\mathrm{mg} / \mathrm{ml}$ ) } \\
\hline & 100 & 200 & 300 & $\begin{array}{l}\text { Control- } \\
\text { Catheter }\end{array}$ & $\begin{array}{l}\text { Control- } \\
\text { Bacteria }\end{array}$ & 100 & 200 & $\begin{array}{r}\text { Control- } \\
\text { Catheter }\end{array}$ & $\begin{array}{r}\text { Control- } \\
\text { Bacteria }\end{array}$ \\
\hline 1 & $0.00 \pm 0.00$ & $0.00 \pm 0.00$ & $0.00 \pm 0.00$ & $5.30 \pm 0.08$ & $5.40 \pm 0.10$ & $0.00 \pm 0.00$ & $0.00 \pm 0.00$ & $5.40 \pm 0.08$ & $5.30 \pm 0.08$ \\
\hline 3 & $0.00 \pm 0.00$ & $0.00 \pm 0.00$ & $0.00 \pm 0.00$ & $5.43 \pm 0.05$ & $5.60 \pm 0.08$ & $0.00 \pm 0.00$ & $0.00 \pm 0.00$ & $5.60 \pm 0.05$ & $5.43 \pm 0.05$ \\
\hline 7 & $0.00 \pm 0.00$ & $0.00 \pm 0.00$ & $0.00 \pm 0.00$ & $5.56 \pm 0.05$ & $5.70 \pm 0.10$ & $0.00 \pm 0.00$ & $0.00 \pm 0.00$ & $5.70 \pm 0.05$ & $5.56 \pm 0.05$ \\
\hline 14 & $0.00 \pm 0.00$ & $0.00 \pm 0.00$ & $0.00 \pm 0.00$ & $5.70 \pm 0.00$ & $5.73 \pm 0.05$ & $0.00 \pm 0.00$ & $0.00 \pm 0.00$ & $5.73 \pm 0.00$ & $5.70 \pm 0.00$ \\
\hline 21 & $0.00 \pm 0.00$ & $0.00 \pm 0.00$ & $0.00 \pm 0.00$ & $5.70 \pm 0.00$ & $5.73 \pm 0.05$ & $0.00 \pm 0.00$ & $0.00 \pm 0.00$ & $5.73 \pm 0.00$ & $5.70 \pm 0.00$ \\
\hline
\end{tabular}

Table 3 The mean \pm SD of the number of colonies formed with E.coli on GTE-IMC, ZIE-IMC, Control-Catheter, and Control-Bacteria in 21 days.

Colonization of E.coli (CFU/ml)

GTE-IMC (concentration $\mathrm{mg} / \mathrm{ml}$ ) $\quad$ ZIE-IMC (concentration $\mathrm{mg} / \mathrm{ml}$ )

\begin{tabular}{|c|c|c|c|c|c|c|c|c|c|c|c|}
\hline Day & 50 & 100 & 200 & 300 & $\begin{array}{l}\text { Control- } \\
\text { Catheter }\end{array}$ & $\begin{array}{l}\text { Control- } \\
\text { Bacteria }\end{array}$ & 50 & 100 & 200 & $\begin{array}{l}\text { Control- } \\
\text { Catheter }\end{array}$ & $\begin{array}{l}\text { Control- } \\
\text { Bacteria }\end{array}$ \\
\hline 1 & $4.70 \pm 0.00$ & $4.70 \pm 0.00$ & $4.60 \pm 0.05$ & $4.60 \pm 0.00$ & $5.30 \pm 0.08$ & $5.40 \pm 0.10$ & $4.56 \pm 0.05$ & $4.50 \pm 0.00$ & $4.60 \pm 0.00$ & $5.30 \pm 0.08$ & $5.40 \pm 0.10$ \\
\hline 3 & $4.63 \pm 0.05$ & $4.50 \pm 0.00$ & $4.53 \pm 0.05$ & $4.40 \pm 0.00$ & $5.43 \pm 0.05$ & $5.60 \pm 0.08$ & $4.56 \pm 0.05$ & $4.50 \pm 0.00$ & $2.86 \pm 2.48$ & $5.43 \pm 0.05$ & $5.60 \pm 0.08$ \\
\hline 7 & $4.63 \pm 0.05$ & $4.40 \pm 0.00$ & $4.40 \pm 0.00$ & $4.00 \pm 0.00$ & $5.56 \pm 0.05$ & $5.70 \pm 0.10$ & $0.00 \pm 0.00$ & $0.00 \pm 0.00$ & $0.00 \pm 0.00$ & $5.56 \pm 0.05$ & $5.70 \pm 0.10$ \\
\hline 14 & $4.23 \pm 0.05$ & $4.10 \pm 0.05$ & $4.00 \pm 0.00$ & $3.70 \pm 0.00$ & $5.70 \pm 0.00$ & $5.73 \pm 0.05$ & $0.00 \pm 0.00$ & $0.00 \pm 0.00$ & $0.00 \pm 0.00$ & $5.70 \pm 0.00$ & $5.73 \pm 0.05$ \\
\hline 21 & $4.30 \pm 0.05$ & $4.10 \pm 0.05$ & $4.00 \pm 0.00$ & $3.60 \pm 0.00$ & $5.70 \pm 0.00$ & $5.73 \pm 0.05$ & $0.00 \pm 0.00$ & $0.00 \pm 0.00$ & $0.00 \pm 0.00$ & $5.70 \pm 0.00$ & $5.73 \pm 0.05$ \\
\hline
\end{tabular}

Table 4 The mean \pm SD the number of colonies formed with S. aureus on EUE-IMC, ROE-IMC, Control-Catheter, and Control-Bacteria in 21 days.

\begin{tabular}{|c|c|c|c|c|c|c|c|c|c|}
\hline \multicolumn{10}{|c|}{ Colonization of S.aureus (CFU/ml) } \\
\hline \multirow[b]{2}{*}{ Day } & \multicolumn{5}{|c|}{ IMC-EUE (concentration mg/ml) } & \multicolumn{4}{|c|}{ IMC-ROE (concentration mg/ml) } \\
\hline & 100 & 200 & 300 & $\begin{array}{l}\text { Control- } \\
\text { Catheter }\end{array}$ & $\begin{array}{l}\text { Control- } \\
\text { Bacteria }\end{array}$ & 100 & 200 & $\begin{array}{l}\text { Control- } \\
\text { Catheter }\end{array}$ & $\begin{array}{l}\text { Control- } \\
\text { Bacteria }\end{array}$ \\
\hline 1 & $1.36 \pm 0.00$ & $0.00 \pm 0.00$ & $0.00 \pm 0.00$ & $5.30 \pm 0.08$ & $5.30 \pm 0.08$ & $0.00 \pm 0.00$ & $0.00 \pm 0.00$ & $5.30 \pm 0.08$ & $5.30 \pm 0.08$ \\
\hline 3 & $0.00 \pm 0.00$ & $0.00 \pm 0.00$ & $0.00 \pm 0.00$ & $5.43 \pm 0.05$ & $5.43 \pm 0.05$ & $0.00 \pm 0.00$ & $0.00 \pm 0.00$ & $5.43 \pm 0.05$ & $5.43 \pm 0.05$ \\
\hline 7 & $0.00 \pm 0.00$ & $0.00 \pm 0.00$ & $0.00 \pm 0.00$ & $5.56 \pm 0.05$ & $5.56 \pm 0.05$ & $0.00 \pm 0.00$ & $0.00 \pm 0.00$ & $5.56 \pm 0.05$ & $5.56 \pm 0.05$ \\
\hline 14 & $0.00 \pm 0.00$ & $0.00 \pm 0.00$ & $0.00 \pm 0.00$ & $5.70 \pm 0.00$ & $5.70 \pm 0.00$ & $0.00 \pm 0.00$ & $0.00 \pm 0.00$ & $5.70 \pm 0.00$ & $5.70 \pm 0.00$ \\
\hline 21 & $0.00 \pm 0.00$ & $0.00 \pm 0.00$ & $0.00 \pm 0.00$ & $5.70 \pm 0.00$ & $5.70 \pm 0.00$ & $0.00 \pm 0.00$ & $0.00 \pm 0.00$ & $5.70 \pm 0.00$ & $5.70 \pm 0.05$ \\
\hline
\end{tabular}

Table 5 The mean \pm SD of the number of colonies formed with S. aureus on GTE-IMC, ZIE-IMC, Control-Catheter, and Control-Bacteria in 21 days. 
Colonization of E.coli (CFU/ml)

\begin{tabular}{|c|c|c|c|c|c|c|c|c|c|c|c|}
\hline \multirow[b]{2}{*}{ Day } & \multicolumn{7}{|c|}{ GTE-IMC (concentration $\mathrm{mg} / \mathrm{ml}$ ) } & \multicolumn{4}{|c|}{ ZIE-IMC (concentration $\mathrm{mg} / \mathrm{ml}$ ) } \\
\hline & 50 & 100 & 200 & 300 & $\begin{array}{l}\text { Control- } \\
\text { Catheter }\end{array}$ & $\begin{array}{l}\text { Control- } \\
\text { Bacteria } \\
\end{array}$ & 50 & 100 & 200 & $\begin{array}{l}\text { Control- } \\
\text { Catheter }\end{array}$ & $\begin{array}{r}\text { Control- } \\
\text { Bacteria }\end{array}$ \\
\hline 1 & $4.83 \pm 0.05$ & $4.70 \pm 0.00$ & $0.00 \pm 0.00$ & $0.00 \pm 0.00$ & $5.30 \pm 0.08$ & $5.30 \pm 0.08$ & $4.56 \pm 0.05$ & $4.50 \pm 0.00$ & $4.36 \pm 0.00$ & $5.30 \pm 0.08$ & $5.30 \pm 0.08$ \\
\hline 3 & $4.83 \pm 0.05$ & $4.70 \pm 0.00$ & $0.00 \pm 0.00$ & $0.00 \pm 0.00$ & $5.43 \pm 0.05$ & $5.43 \pm 0.05$ & $4.56 \pm 0.05$ & $4.50 \pm 0.00$ & $0.00 \pm 0.00$ & $5.43 \pm 0.05$ & $5.43 \pm 0.05$ \\
\hline 7 & $4.80 \pm 0.83$ & $4.40 \pm 0.00$ & $0.00 \pm 0.00$ & $0.00 \pm 0.00$ & $5.56 \pm 0.05$ & $5.56 \pm 0.05$ & $0.00 \pm 0.00$ & $0.00 \pm 0.00$ & $0.00 \pm 0.00$ & $5.56 \pm 0.05$ & $5.56 \pm 0.05$ \\
\hline 14 & $4.80 \pm 0.83$ & $4.36 \pm 0.05$ & $0.00 \pm 0.00$ & $0.00 \pm 0.00$ & $5.70 \pm 0.00$ & $5.70 \pm 0.00$ & $0.00 \pm 0.00$ & $0.00 \pm 0.00$ & $0.00 \pm 0.00$ & $5.70 \pm 0.00$ & $5.70 \pm 0.00$ \\
\hline 21 & $4.40 \pm 0.00$ & $4.30 \pm 0.05$ & $0.00 \pm 0.00$ & $0.00 \pm 0.00$ & $5.70 \pm 0.00$ & $5.70 \pm 0.00$ & $0.00 \pm 0.00$ & $0.00 \pm 0.00$ & $0.00 \pm 0.00$ & $5.70 \pm 0.00$ & $5.70 \pm 0.05$ \\
\hline
\end{tabular}

The Bacteria in the environment are killed within 21 days, which can indicate that the release of the extract from the catheter over time could be effect on planktonic bacteria[33].(Fig 6.)

Attenuated total reflectance Fourier transform infrared (ATR-FTIR) was used to indicate the penetration of the extracts into the catheters. The ATR-FTIR analysis was used to show the amount of the extracts penetrated into the polymer as well as the chemical properties of the coated catheters (Fig 7.).

Accordingly, the ATR-FTIR spectra of the EUE-IMC, ROE-IMC, GTE-IMC, and ZIE-IMC catheters are shown in Fig. 4 and Table 6. As it can be seen, , the peak of O-H group blended in the hydroxyl compounds of EUE-IMC, GTE-IMC, ROE-IMC and ZIE-IMC catheters is located at 3335, 3346, 3350 and $3330 \mathrm{~cm}^{-1}$ [34-36]. Moreover, the carboxylic group $(\mathrm{C}=0)$ of the different extracts related to EUE-IMC, ROE-IMC, GTE-IMC and ZIE-IMC is located at1712, 1689, 1691 and $1707 \mathrm{~cm}^{-1}[37-39]$. The decrease of peak in 2917, 2916, 1280 and $1006 \mathrm{~cm}^{-1}$ EUE-IMC spectra indicates that the EUE extract coating on the polymer surface[39]. Based on four spectra the EUE has more absorption on the surface of catheters than other extracts. The aromatic rings of ROE-IMC, GTE-IMC AMD ZIE-IMC were located on 681,686 and1515 cm ${ }^{1}[40-41] .($ Table 6.) and (Fig 8.)

Table 6 Characteristics of ATR-FTIR absorption bands in Silicone catheter, EUE-IMC, ROE-IMC.GTE-IMC and ZIE-IMC

\begin{tabular}{ccc}
\hline$\left(\mathrm{cm}^{-1}\right)$ Wave number & Bond & Reference \\
\hline $1445-1455$ & $\mathrm{Ar} \mathrm{OH}$ & {$[35]$} \\
$3200-2800$ & OH stretch in a carboxylic acid & {$[42]$} \\
$2966-2962$ & $\mathrm{CH}$ in $\mathrm{CH}$ & {$[43]$} \\
$1715-1705$ & $\mathrm{RCO}-\mathrm{OH}$ & {$[38]$} \\
$1645-1637$ & $\mathrm{C}=\mathrm{C}$ & {$[35]$} \\
$1695-1685$ & $\mathrm{C}=\mathrm{C}-\mathrm{CO}-\mathrm{OH}$ & {$[37]$} \\
$1600-1580$ & $\mathrm{C}=\mathrm{C}$ & {$[36]$} \\
$1520-1513$ & $\mathrm{C}-\mathrm{H}\left(\mathrm{CH}_{3}\right)$ & {$[36]$} \\
$1440-1390$ & $\mathrm{CH}_{3}$ in $\mathrm{Si}-\mathrm{CH}_{3}$ & {$[43]$} \\
$1420-1330$ & $\mathrm{OH}$ & {$[35]$} \\
$1280-1240$ & $\mathrm{Si}\left(\mathrm{CH}_{3}\right)_{3}$ & {$[43]$} \\
$1100-1000$ & $\mathrm{Si}-\mathrm{O}_{3}-\mathrm{Si}$ & {$[43]$} \\
$870-856$ & $\mathrm{Si}\left(\mathrm{CH}_{3}\right)_{3}$ & {$[43]$} \\
$840-790$ & $\mathrm{Si}\left(\mathrm{CH}_{3}\right)_{2}$ & {$[43]$} \\
700 & $\mathrm{Si}\left(\mathrm{CH}_{3}\right)_{2}$ & {$[43]$} \\
\hline
\end{tabular}

The hydrophobic surface of the silicone rubber caused the bacteria to adhere to the surface of them, leading to the formation of biofilms. Accordingly, the silicone rubber hydrophilicity should be increased to prevent the adhesion of bacteria[10]. The physicochemical interactions include electrostatic, van der Waals, and acid bases interplay. This interplay depends on the substance and the bacterial surface's physicochemical attributes: such as hydrophobicity[44].

As shown in Fig. 9, the water contact angle of the impregnated catheter by Eucalyptus, Rosemary, Green tea and Ziziphora's extracts decreased, so the hydrophilicity increased, too, due to the coating of the IMC surface by the herbal extracts. Moreover, the bacteria adhesion to the surface depends on the natural bacteria and the target surface. The hydrophilic surface is more resistant to the sticking bacteria[9].

Because of the hydrophilic groups of the rosemary ethanolic extract available at the top surface of ROE-IMC samples, the wettability effect of the surface was obtained. The rosmarinic acid has $4(\mathrm{OH})$ groups and $1(\mathrm{COOH})$ group, so it shows more polar and hydrophilic properties. Accordingly, in this ethanol-water solution, ROE released rosmarinic acid more[45]. The contact angle for the droplets on the surface of the silicone catheters impregnated by green tea and ziziphora extracts became less than that of the silicone Foley catheter which indicates their hydrophilic effect. The (-)-epigallocatechin gallate is the major compound in the green tea extract which is a hydrophilic natural compound[46]. The hydroxyl group position was different in the similar structure of thymol and carvacrol. In the 
Thymol, the hydroxyl group is close to the short-chain of isopropyl. On the other hand, in the carvacrol, the hydroxyl group is close to the methyl group. So, thymol is more non-polar than carvacrol[47].

In this research, we may have extracted carvacrol more than thymol. The surface topography of the EUE-IMC, GTE-IMC and NON-IMC catheters was examined by AFM. As it can be seen in Fig. 10, the surface modification had a detrimental effect on the surface property of catheters.

The IMC samples were soaked in the solution for 1 hour. While the NON-IMC surface (not soaked) had a smooth morphology, the roughness of the EUE-IMC and GTE-IMC surface increased a little (illustrated by Fig. 10). The increased roughness can be due to the swelling of the catheters and changes in polymer volume[48].

The amount of the bacterium Staphylococcus aureus on the NON-IMC samples was compared with those of EUE-IMC, ROE-IMC, GTE-IMC and ZIE-IMC samples. As it can be observed in Figure 10, the amount of the bacteria sticking to the surface of the NON-IMC catheter is higher compared with the bacteria adhesion to the other four impregnated catheters because of their hydrophilic surfaces. The phenolic compounds react to the protein and cell wall structures of bacteria; they may damage the cytoplasmic membranes, reduce membrane fluidity, and inhibit nucleic acid synthesis, cell wall synthesis, or energy metabolism[49].

The mechanical test results before and after soaking the catheters in the P.B.S is also demonstrated in Table 7

Table 7 The results of the mechanical test of catheters before and after 21 days in the P.B.S.

\begin{tabular}{|c|c|c|c|c|c|c|}
\hline \multicolumn{7}{|c|}{ Before 21 days in P.B.S } \\
\hline Samples & Max force [N] & Max elongation & {$[\mathrm{mm}]$} & Yield stress [Mpa] & Break strain [\%] & Young modulus [Mpa] \\
\hline NON-IMC & 100.94 & 2.37 & & 0.300 & 651.400 & 19.625 \\
\hline EUE-IMC & 84.28 & 2.26 & & 0.277 & 618.233 & 19.313 \\
\hline ROE-IMC & 88.20 & 2.20 & & 0.207 & 523.567 & 19.419 \\
\hline GTE-IMC & 99.12 & 2.30 & & 0.202 & 485.900 & 19.390 \\
\hline ZIE-IMC & 92.120 & 2.33 & & 0.222 & 682.167 & 19.466 \\
\hline \multicolumn{7}{|c|}{ After 21 days in P.B.S } \\
\hline NON-IMC & 165.62 & 2.07 & & 0.186 & 822.500 & 20.901 \\
\hline EUE-IMC & 162.68 & 2.33 & & 0.233 & 747.976 & 18.999 \\
\hline ROE-IMC & 163.22 & 2.03 & & 0.218 & 835.400 & 19.736 \\
\hline GTE-IMC & 166.40 & 2.45 & & 0.231 & 831.767 & 18.843 \\
\hline ZIE-IMC & 163.44 & 2.50 & & 0.230 & 820.830 & 19.322 \\
\hline
\end{tabular}

Based on the results obtained from the tensile test, it can be said that the break strain in silicone catheters before and after impregnation was not different. The Break strain before and after swilling catheters in the phosphate buffer is not much change. As shown in Table 7 , Young modulus of silicone catheters is not change before and after impregnation; the Young module of catheters increased after the swilling in p.b.s. When a thermodynamically compatible solvent is in contact with uncross-linked amorphous glassy polymer, it will be plasticizated by the solvent diffusion[50]. When some solvent remaines in the polymer (after its swelling in the solvent), it plays the role of a plasticizer. Consequently, due to the flexibility of the film, the Young module increases. Initially, the modulus of elasticity decreases due to the opening of the coiled chain. But after the chains are opened, the elastic deformation increases as the bonds are pulled, resulting in an increase in the modulus of elasticity[51].

\section{Conclusion}

The Foley catheters that are currently used in hospitals can lead to urinary tract infections. Besides, different bacteria become more resistent to the chemical antibiotics during the passage of time, which this, by itself, can increase the hospital costs and the mortality rate of patients. Various studies have been carried out to modify catheters by using a variety of antibacterial agents such as silver or chemical antibiotics. In this study, we intended to keep on the past studies by using the medicinal herbs agent to impregnate the silicone catheters. Our experiments showed that the silicone catheter, impregnated by Eucalyptus and Rosemary, have significant bactericidal effects on two major bacteria, i.e. Escherichia coli and Staphylococcus aureus, and also prevent their biofilm formation, thereby they can reduce the urinary tract infections and hospital costs. Moreover, the hydrophilic effect of the surface of IMC catheters increased and reduced the bacteria adhesion to them. The IMC catheters could also reduce the bacteria colonization. However, this impregnation method increases the surface roughness of the catheters compared with that of the NON-IMC samples.

\section{Declarations}

\section{- Funding}


No funding

\section{- Authors' contributions}

All authors read and approved the final manuscript

\section{- Acknowledgements}

Not applicable

\section{- Authors' information (optional)}

No information

\section{- Ethics approval and consent to participate}

Not applicable

\section{- Consent for publication}

Not applicable

\section{- Availability of data and material}

Availability of data and materials' statement

\section{- Competing interests}

The authors whose names are listed immediately below certify that they have NO affiliations with or involvement in any organization or entity with any financial interest (such as honoraria; educational grants; participation in speakers' bureaus; membership, employment, consultancies, stock ownership, or other equity interest; and expert testimony or patent-licensing arrangements), or non-financial interest (such as personal or professional relationships, affiliations, knowledge or beliefs) in the subject matter or materials discussed in this manuscript.

The authors whose names are listed immediately below report the following details of affiliation or involvement in an organization or entity with a financial or non-financial interest in the subject matter or materials discussed in this manuscript. Please specify the nature of the conflict on a separate sheet of paper if the space below is inadequate

\section{Author names:}

Najme Akhlaghi-Ardekani, Davod Mohebbi-Kalhori, Abdolreza samimi, Reza Karazhyan

\section{References}

1. Shuman EK, Chenoweth CE. Urinary Catheter-Associated Infections. Infect Dis Clin North Am. 2018;32(4):885-97.

2. Tuson HH, Weibel DB. Bacteria-surface interactions. Soft Mater. 2013;9(17):4368-80.

3. Bhalodia NR, Shukla V. Antibacterial and antifungal activities from leaf extracts of Cassia fistula I.: An ethnomedicinal plant, J Adv Pharm Tech Res. 2011. 104-09. 10.4103/2231-4040.82956.

4. Quave CL, Estévez-Carmona M, Compadre CM, Hobby G, Hendrickson H, Beenken KE, et al. Ellagic acid derivatives from Rubus ulmifolius inhibit Staphylococcus aureus biofilm formation and improve response to antibiotics. PLoS One. 2012;7(1).

5. Martin C, Hoven A, Cook A. Therapeutic frontiers: preventing and treating infectious diseases by inhibiting bacterial quorum sensing. Eur J Clin Microbiol Infect Dis. 2008;27(8):635-42.

6. Bilal M, Erum S, Huang D, Che S. Optimization of antibacterial activity of Eucalyptus tereticornis leaf extracts against Escherichia coli through response surface methodology. J Radiat Res Appl SC. 2016;9(4):376-85.

7. Ahmadi Moghadam M, Shahraki M. Comparison of Nociceptive Effect of Ziziphora tenuior L. Hydroalcoholic Extract and Diclofenac Using Formaline Test in Male Rats. HorizBiochemBiophys. 2015;20(4):209-14.

8. Trooskin S, Donetz A, Harvey R, Greco R. Prevention of catheter sepsis by antibiotic bonding. Surgery. 1985;97(5):547-51. 
9. Ding X, Yang C, Lim TP, Hsu LY, Engler AC, Hedrick JL, et al. Antibacterial and antifouling catheter coatings using surface grafted PEGb-cationic polycarbonate diblock copolymers. Biomaterials. 2012;33(28):6593-603.

10. Rodrigues L, Van Der Mei H, Banat IM, Teixeira J, Oliveira R. Inhibition of microbial adhesion to silicone rubber treated with biosurfactant from Streptococcus thermophilus A. FEMS Immunol Med Microbiol. 2006;46(1):107-12.

11. Saint S, Chenoweth CE. Biofilms and catheter-associated urinary tract infections. Infect Dis Clin North Am. 2003;17(2):411-32.

12. Hamadi $F$, Latrache $H$, Zahir $H$, Elghmari A, Timinouni M, Ellouali $M$. The relation between Escherichia coli surface functional groups' composition and their physicochemical properties. Braz J Microbiol. 2008;39(1):10-5.

13. Oliveira RN, Mancini MC, Oliveira FCS, d, Passos TM, Quilty B, Thiré R M d S M, et al. FTIR analysis and quantification of phenols and flavonoids of five commercially available plants extracts used in wound healing. Matéria (Rio de Janeiro). 2016;21(3):767 - 79.

14. Plavšić DV, Škrinjar MM, Psodorov ĐB, Pezo LL, Milovanović IL, Psodorov D, et al. Chemical structure components and antifungal activity of mint essential oil. J Serb Chem Soc. 2020;17-17.

15. Darie-Niţă R, Vasile C, Stoleru E, Pamfil D, Zaharescu T, Tarţău L, et al. Evaluation of the Rosemary Extract Effect on the Properties of Polylactic Acid-Based Materials. Materials. 2018;11(10):1-33.

16. Yazdi FT, Mortazavi A, Koocheki A, Afsharian S, Behbahani BA. Antimicrobial properties of plant extracts of Thymus vulgaris $L$., Ziziphora tenuior L. and Mentha Spicata L., against important foodborne pathogens in vitro. Sci. J. Microbiol.

17. . 2013;2(2):23-30.

18. Johnson R, Bryant S, Huntley AL. Green tea and green tea catechin extracts: an overview of the clinical evidence. Maturitas. 2012;73(4):280-87.

19. Anzabi Y, Khaki A. antibacterial activity of ziziphora tenuior lam. extract and essential oil against bacteria isolated from urogenital tract infections. J Clin Lab Med. 2016;10:54-9.

20. Raoof GFA, Mohamed KY, Natural Products for the Management of Diabetes, in Studies in Natural Products Chemistry. 2018, Elsevier. p. $323-74$.

21. Rodrigues VH, de Melo MM, Portugal I, Silva CM. Extraction of Eucalyptus leaves using solvents of distinct polarity. Cluster analysis and extracts characterization. J. Supercrit. Fluids. 2018;135(263 - 74.

22. Bayston R, Grove NJ, Antimicrobial device and method. 1990, Google Patents.

23. Azmir J, Zaidul I, Rahman M, Sharif K, Mohamed A, Sahena F, et al. Techniques for extraction of bioactive compounds from plant materials: a review. J Food Eng. 2013;117(4):426-36.

24. Fisher LE, Hook AL, Ashraf W, Yousef A, Barrett DA, Scurr DJ, et al. Biomaterial modification of urinary catheters with antimicrobials to give long-term broadspectrum antibiofilm activity. J Control Release. 2015;202:57-64.

25. Kowalczuk D, Ginalska G, Golus J. Characterization of the developed antimicrobial urological catheters. Int J Pharm. 2010;402(12):175-83.

26. Wiegand I, Hilpert K, Hancock RE. Agar and broth dilution methods to determine the minimal inhibitory concentration (MIC) of antimicrobial substances. 2008;3(2):163.

27. Slane J, Vivanco J, Rose W, Ploeg H-L, Squire M. Mechanical, material, and antimicrobial properties of acrylic bone cement impregnated with silver nanoparticles. Mater. Sci. Eng. C Mater. Biol. Appl. 2015;48(188 - 96.

28. Carberry BJ, Farrell J, Kennedy JE. Evaluation and characterisation of urinary catheter coating utilising Hansen solubility parameters and FEA analysis. Suref. Coat. Tech. 2015;276(456- 63.

29. Tenke P, Riedl CR, Jones GL, Williams GJ, Stickler D, Nagy E. Bacterial biofilm formation on urologic devices and heparin coating as preventive strategy. Int J Antimicrob Agents. 2004;23:67-74.

30. Jones GL, Muller C, O'reilly M, Stickler D. Effect of triclosan on the development of bacterial biofilms by urinary tract pathogens on urinary catheters. J Antimicrob Chemother. 2005;57(2):266-72.

31. Gadkari PV, Balaraman M. Catechins. Sources, extraction and encapsulation: A review. Food Bioprod. Process. 2015;93(122 - 38.

32. Ruiz B, Flotats X. Citrus essential oils and their influence on the anaerobic digestion process: An overview. Waste management. 2014;34(11):2063-79.

33. Farag R, Daw Z, Abo-Raya S. Influence of some spice essential oils on Aspergillus parasiticus growth and production of aflatoxins in a synthetic medium. J Food Sci. 1989;54(1):74-6.

34. Viola GM, Rosenblatt J, Raad II. Drug eluting antimicrobial vascular catheters: progress and promise. Adv Drug Deliv Rev. 2017;112:35-47.

Page 10/19 
35. Hajipour F, Asad S, Amoozegar MA, Javidparvar AA, Tang J, Zhong H, et al. Developing a Fluorescent Hybrid Nanobiosensor Based on Quantum Dots and Azoreductase Enzyme forMethyl Red Monitoring. Iran Biomed J. 2020;25(1):8-20.

36. García C, Montero G, Coronado MA, Valdez B, Stoytcheva M, Rosas N, et al. Valorization of Eucalyptus Leaves by Essential Oil Extraction as an Added Value Product in Mexico. waste. biomass. valor.. 2017;8(4):1187-97.

37. Valderrama ACS, De GCR. Traceability of Active Compounds of Essential Oils in Antimicrobial Food Packaging Using a Chemometric Method by ATR-FTIR. Int res j biol sci. 2017;8(11):726-41.

38. Pant M, Dubey S, Patanjali P, Naik S, Sharma S. Insecticidal activity of eucalyptus oil nanoemulsion with karanja and jatropha aqueous filtrates. Int. Biodeter. Biodegr. 2014;91(119 - 27.

39. Tawfeeq A, Mahdi M, Abaas I, Alwan AH, Isolation. Quantification, And Identification Of Rosmarinic Acid, Gas Chromatography-Mass Spectrometry Analysis Of Essential Oil, Cytotoxic Effect, And Antimicrobial Investigation Of Rosmarinus Officinalis Leves. Asian J Pharm Clin Res. 2018;11(6):126-32.

40. Li Y, Ren H, Ragauskas AJ. Rigid polyurethane foam reinforced with cellulose whiskers: Synthesis and characterization. Micro Nanosyst. 2010;2(2):89-94.

41. Javidparvar AA, Naderi R, Ramezanzadeh B, Bahlakeh G. Graphene oxide as a pH-sensitive carrier for targeted delivery of eco-friendly corrosion inhibitors in chloride solution: Experimental and theroretical investigations. J Ind Eng Chem. 2019;72:196-213.

42. Jung MR, Horgen FD, Orski SV, Rodriguez V, Beers KL, Balazs GH, et al. Validation of ATR FT-IR to identify polymers of plastic marine debris, including those ingested by marine organisms. Mar. Pollut. Bull. 2018;127(704 - 16.

43. Senthilkumar S, Sivakumar T, Arulmozhi KT, Mythili N. FT-IR analysis and correlation studies on the antioxidant activity, total phenolics and total flavonoids of India commerical teas (Camellia Sinensis L.) - A novel approach. Int. Res. J. Biological. Sci. 2017;17.

44. Ehsani M, Borsi H, Gockenbach E, Bakhshandeh G, Morshedian J. Modified silicone rubber for use as high voltage outdoor insulators. Polym Adv Technol. 2005;24(1):51-61.

45. Van Loosdrecht M, Lyklema J, Norde W, Schraa G, Zehnder A. The role of bacterial cell wall hydrophobicity in adhesion. Appl Environ Microbiol. 1987;53(8):1893-97.

46. Piñeros-Hernandez D, Medina-Jaramillo C, López-Córdoba A, Goyanes S. Edible cassava starch films carrying rosemary antioxidant extracts for potential use as active food packaging. Food. Hydrocoll. 2017;63(488 - 95.

47. Ignasimuthu K, Prakash R, Murthy PS, Subban N. Enhanced bioaccessibility of green tea polyphenols and lipophilic activity of EGCG octaacetate on gram-negative bacteria. LWT. 2019;105:103-09.

48. Aghamohammadi A, Azadbakht M, Hosseinimehr SJ. Quantification of thymol content in different extracts of Zataria multiflora by HPLC method. Pharm.Biomed.Res. 2016;8-13.

49. Belfield K, Chen X, Smith EF, Ashraf W, Bayston R. An antimicrobial impregnated urinary catheter that reduces mineral encrustation and prevents colonisation by multi-drug resistant organisms for up to 12 weeks. Acta biomater. 2019;157 - 68 .

50. Gyawali R, Ibrahim SA. Natural products as antimicrobial agents. Food Control. 2014;46(412 - 29.

51. Miller-Chou BA, Koenig JL. A review of polymer dissolution. Prog Polym Sci. 2003;28(8):1223-70.

52. Smith WF. Principles of materials science and engineering. 1986.

\section{Figures}



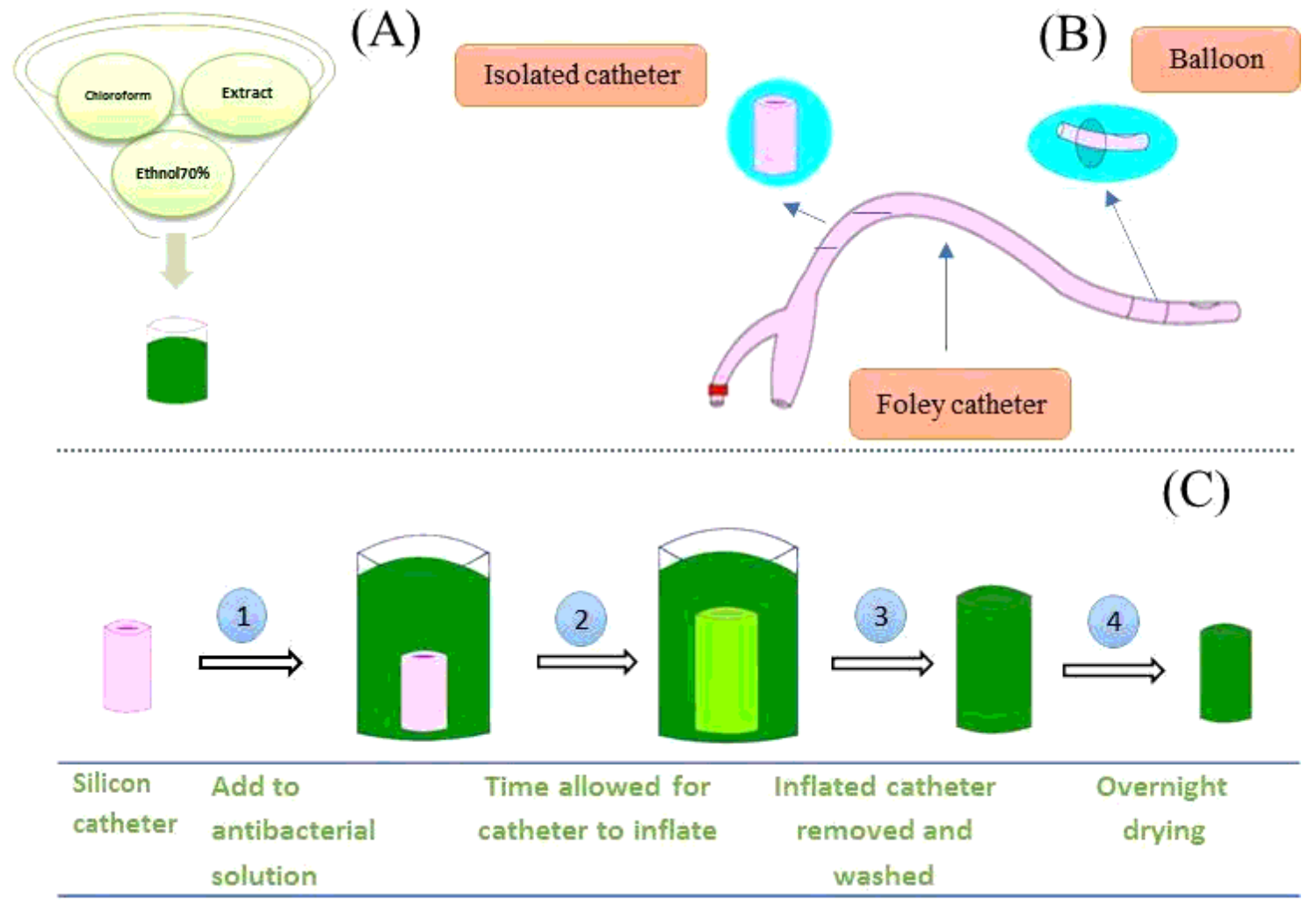

\section{Figure 1}

The illustration of stages are preparing IMC preparation stages.: (A)P preparing the antibacterial solution, (B) Producing the schematic diagram, (C) the impregnation process, including, (1) The addition of the catheters is added to the antibacterial solution, (2) The inflation of the catheters remains in the solution, until it is swollen, (3) The swollen removal of the catheters out of the solution to rinse is removed and rinsed, (4) the It is then exposition of the catheters to an ambient condition to dry and return to theirits original state, (5) . Following this process, we have an antibacterial catheters are ready
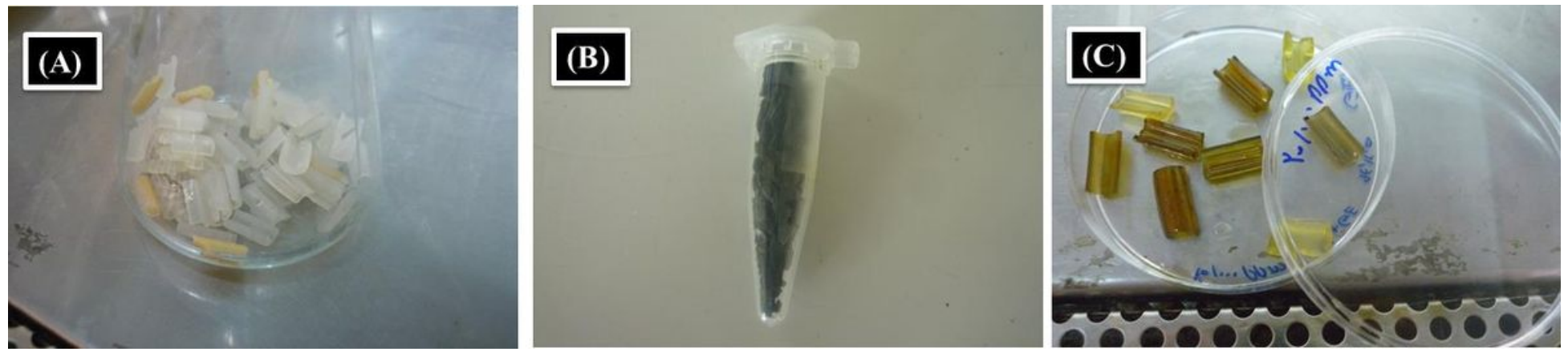

\section{Figure 2}

(A) Non-impregnated catheters. (B) Extracts. (C) Impregnated catheters 

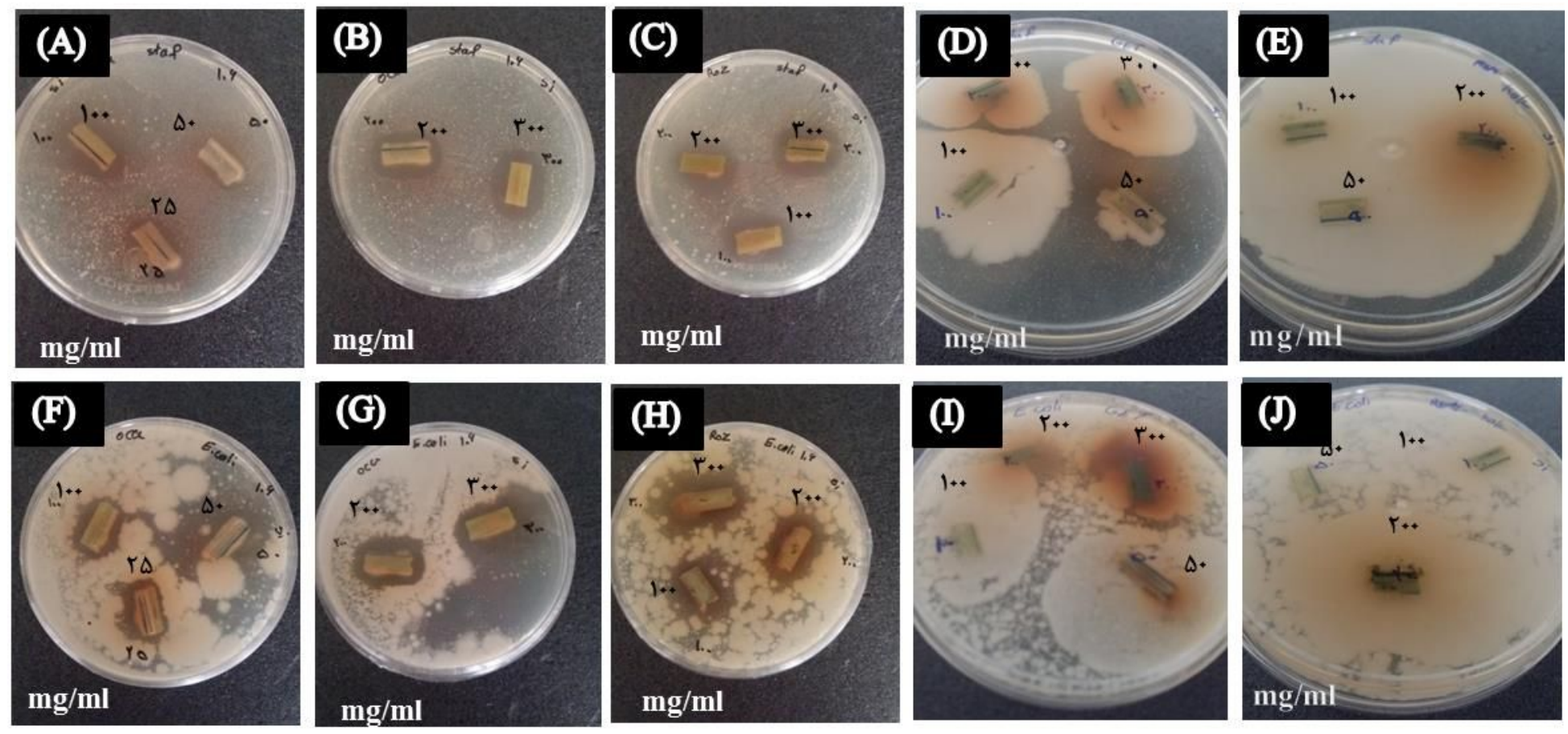

\section{Figure 3}

The EUE-IMC samples with the concentration of 25, $50 \& 100 \mathrm{mg} / \mathrm{ml}$, (B) The EUE-IMC samples with the concentration of $200 \& 300 \mathrm{mg} / \mathrm{ml}$, (C) The ROE-IMC samples with the concentration 100, 200, $200 \& 300 \mathrm{mg} / \mathrm{ml}$, (D) The GET-IMC samples with the concentration of 50, 100, $200 \& 300 \mathrm{mg} / \mathrm{ml}$, and (E) The ZIE-IMC samples with the concentration of 50, $100 \& 200 \mathrm{mg} / \mathrm{ml}$. Pictures related to the zone of inhabitation of Escherichia Coli, (F) The EUE-IMC samples with the concentration of 25, 50 and $100 \mathrm{mg} / \mathrm{ml}$, (G) The EUE-IMC samples with the concentration of 200 and $300 \mathrm{mg} / \mathrm{ml},(\mathrm{H})$ The ROE-IMC samples with the concentration of 100, 200 AND 300 mg/ml, (I) The GTE-IMC samples with the concentration of $50,100,200$ and $300 \mathrm{mg} / \mathrm{ml},(\mathrm{J})$ The ZIE-IMC samples with the concentration of 50,100 and 200 $\mathrm{mg} / \mathrm{ml}$. 

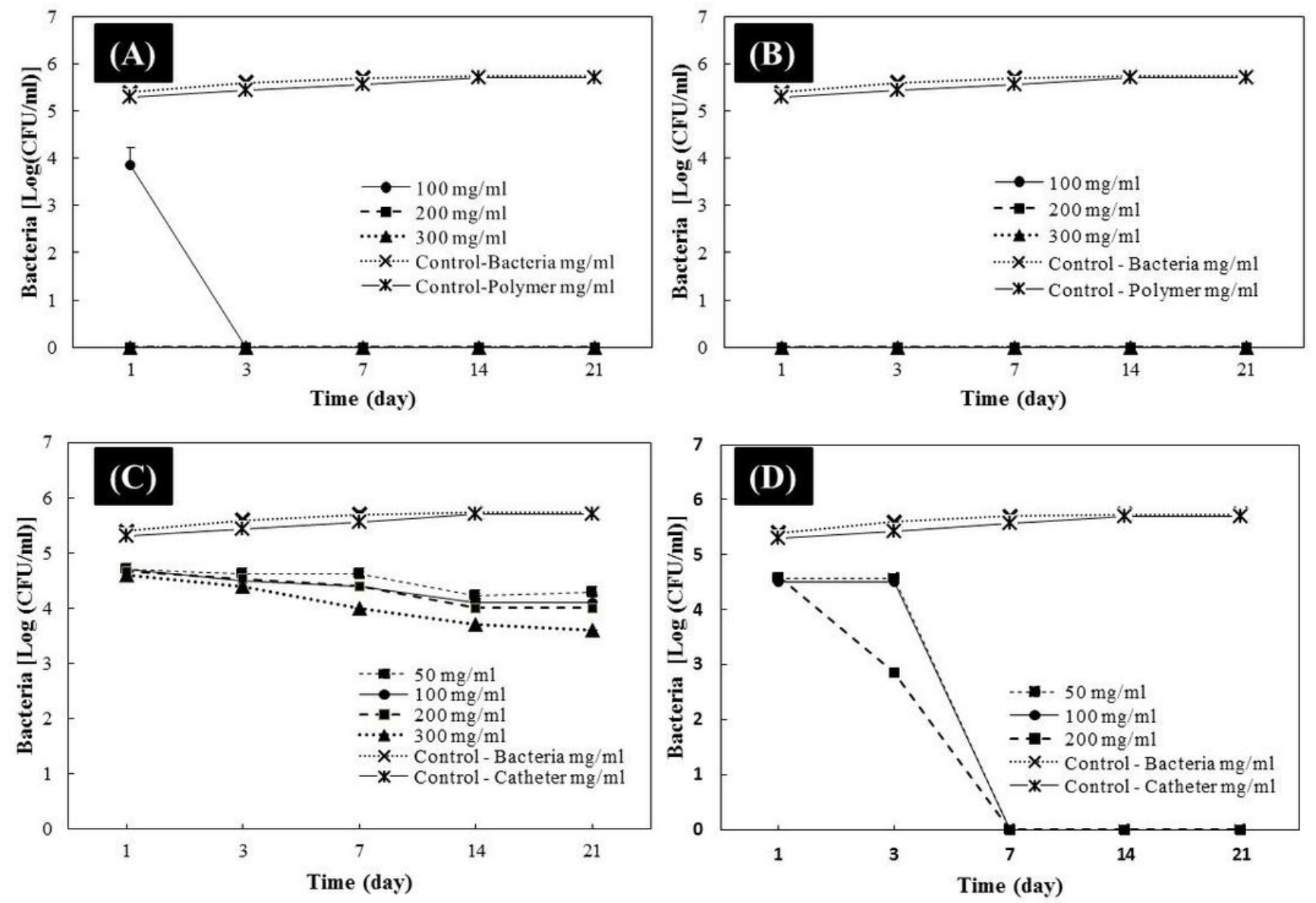

\section{Figure 4}

The mean of the colonies of different concentrations of Escherichia Coli in 21 days: (A) EUE-IMC with concentration of 100, 200 and 300

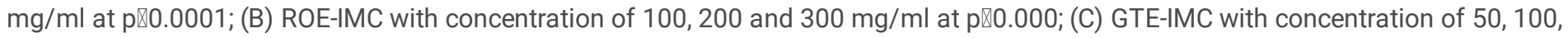

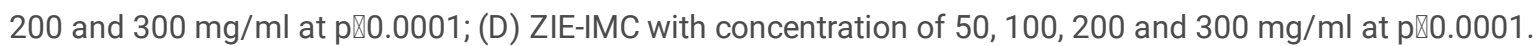



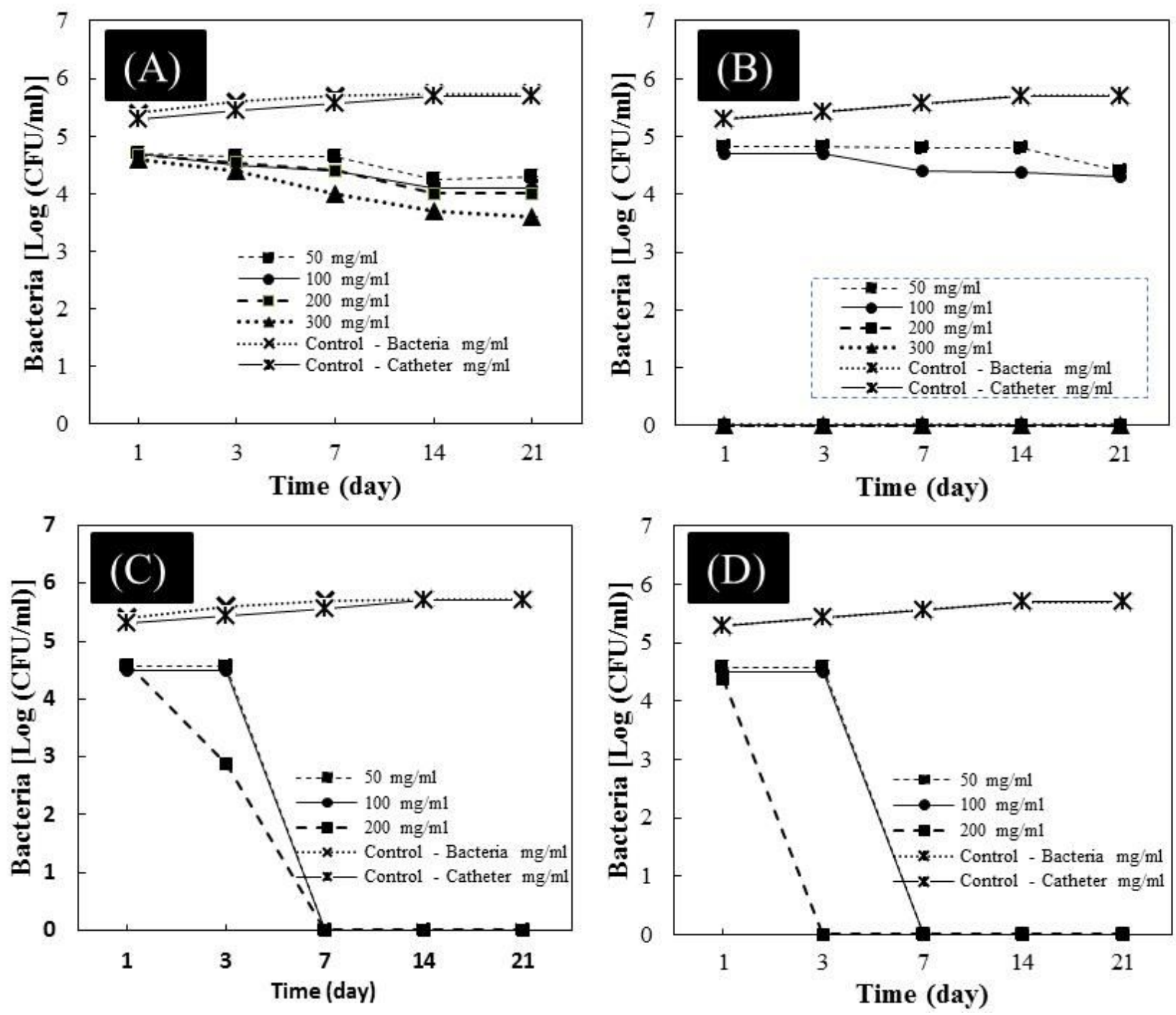

Figure 5

The mean of the colonies of different concentrations of Staphylococcus Aureus in 21 days: (A) EUE-IMC with concentration of 100, 200

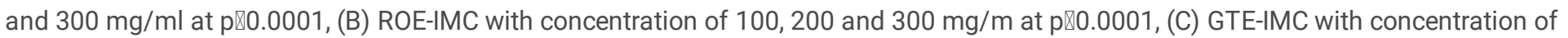
$50,100,200$ and $300 \mathrm{mg} / \mathrm{ml}$ at $\mathrm{p} \otimes 0.0001$, and (D) ZIE-IMC with concentration of 50, 100, 200 and $300 \mathrm{mg} / \mathrm{ml}$ at p $ه 0.0001$. 

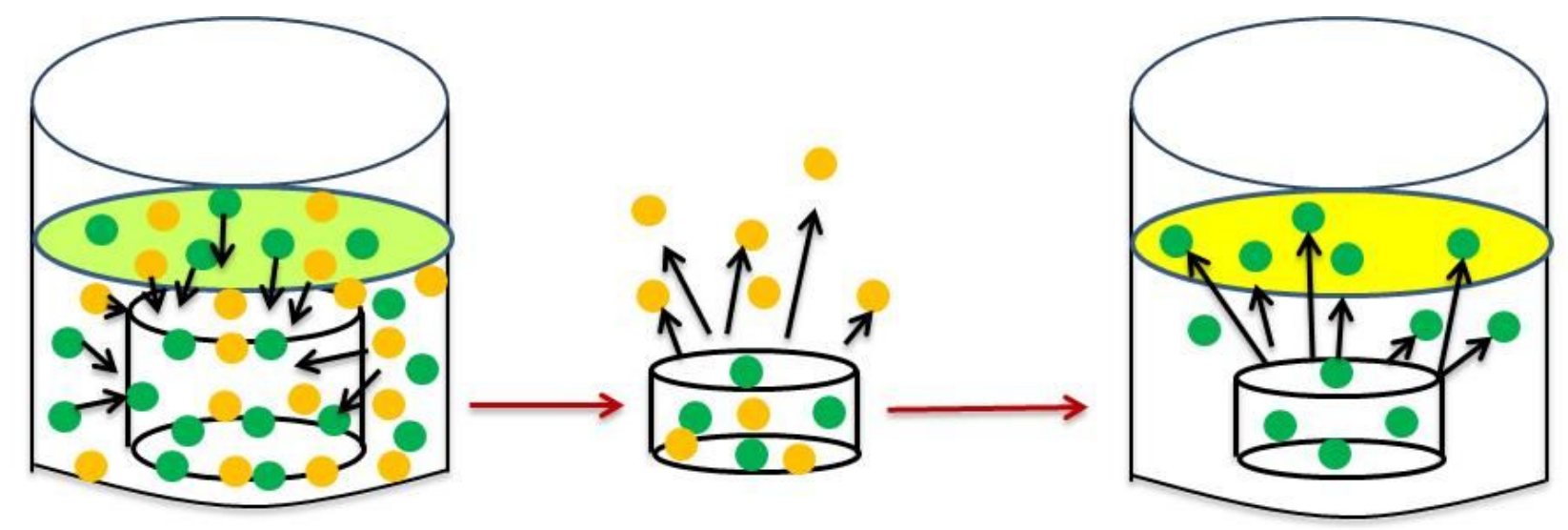

\section{Catheter in the solution of} extract and solvent

Catheter inside the environment and drying Catheter inside the urine and release the extract

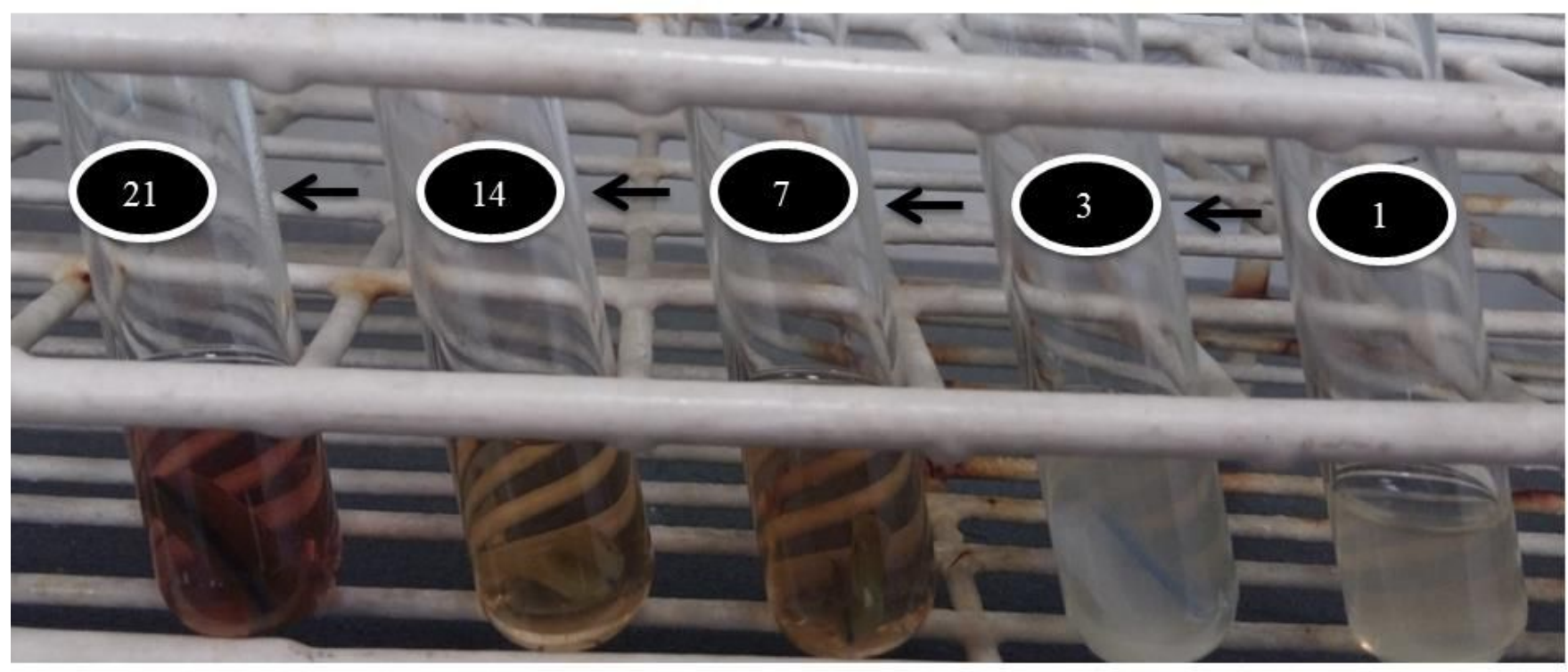

Release of the extract after 21 days

Figure 6

Release the extract from the catheters 


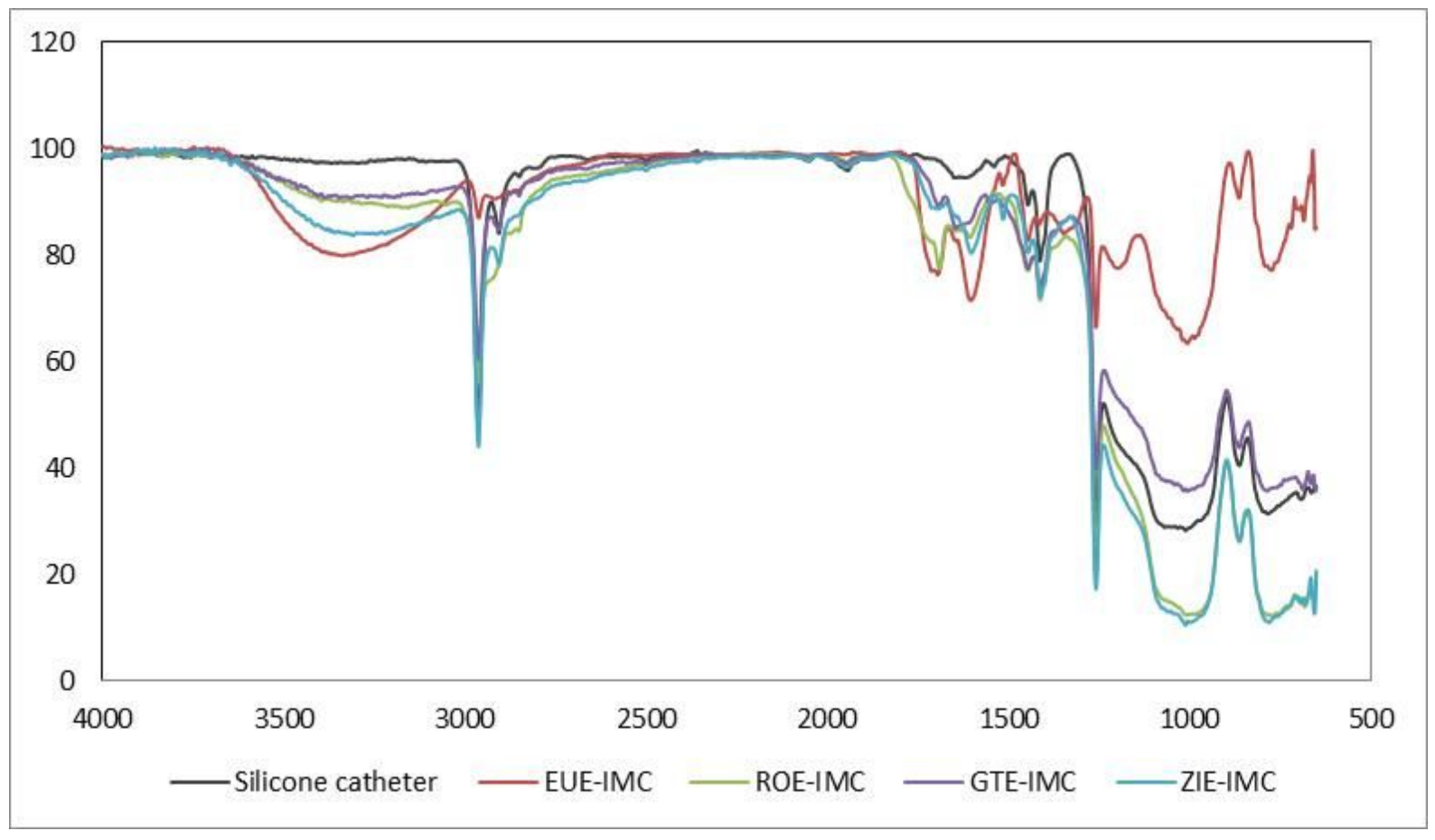

Figure 7

ATR-FTIR spectra

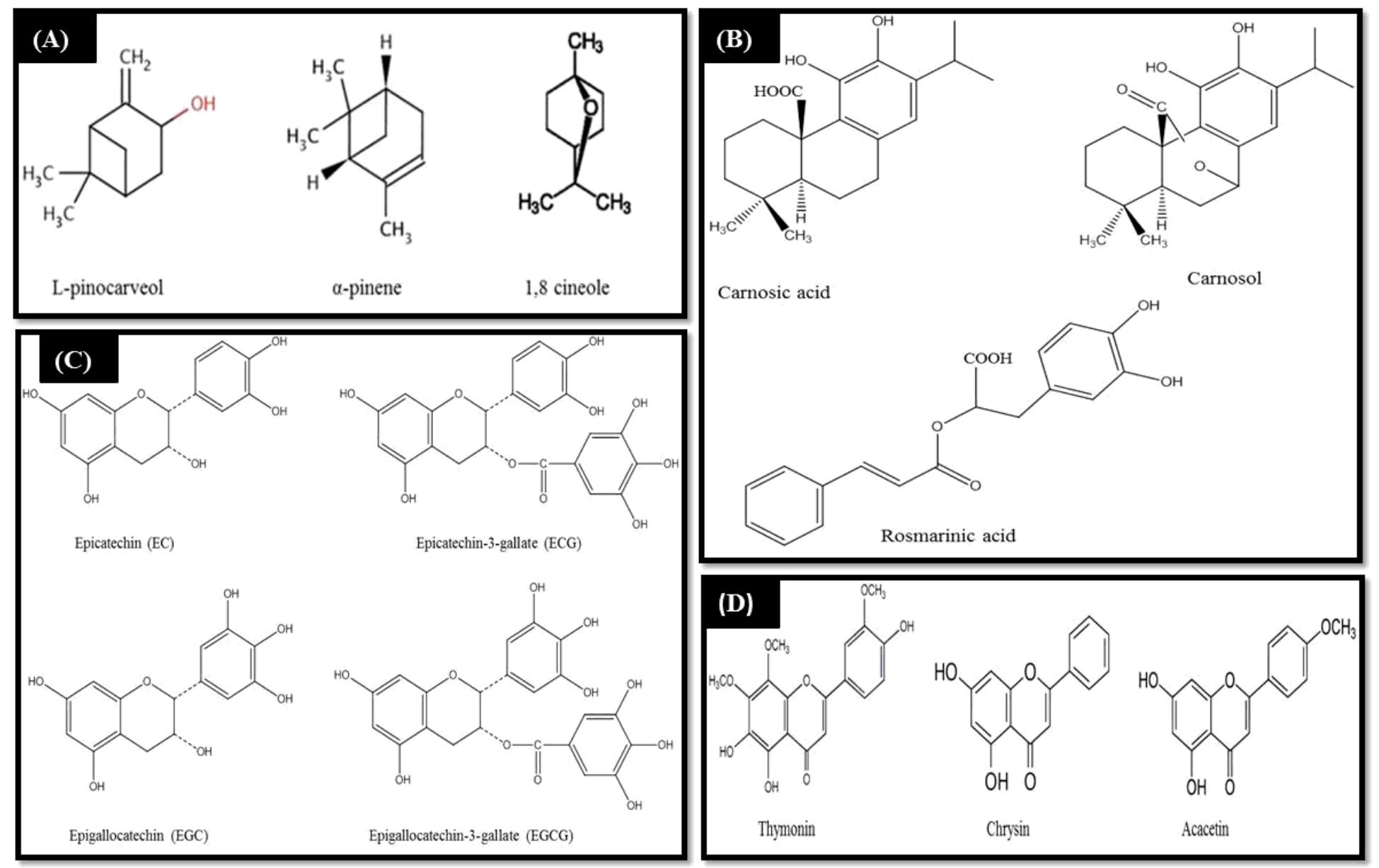

Figure 8

The main compounds in plants extract, (A) EUE-IMC, (B) ROE-IMC, (C) GTE-IMC, (D) ZIE-IMC 

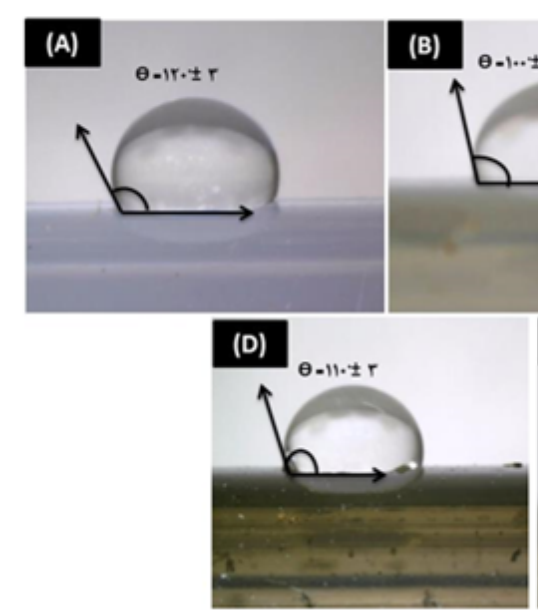

(B)

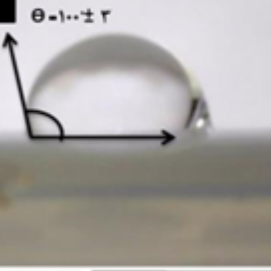

(E)

(c)
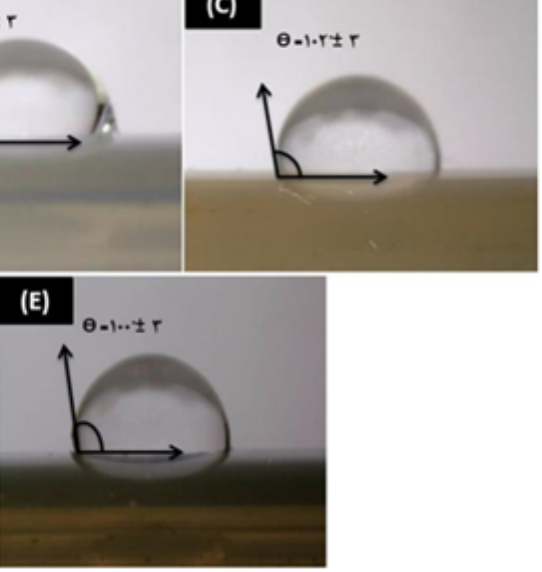

Figure 9

The images taken from the water droplets on the surface. (A) NON-IMC, (B) EUE-IMC, (C) ROE-IMC, (D) GTE-IMC, and (E) ZIE-IMC.
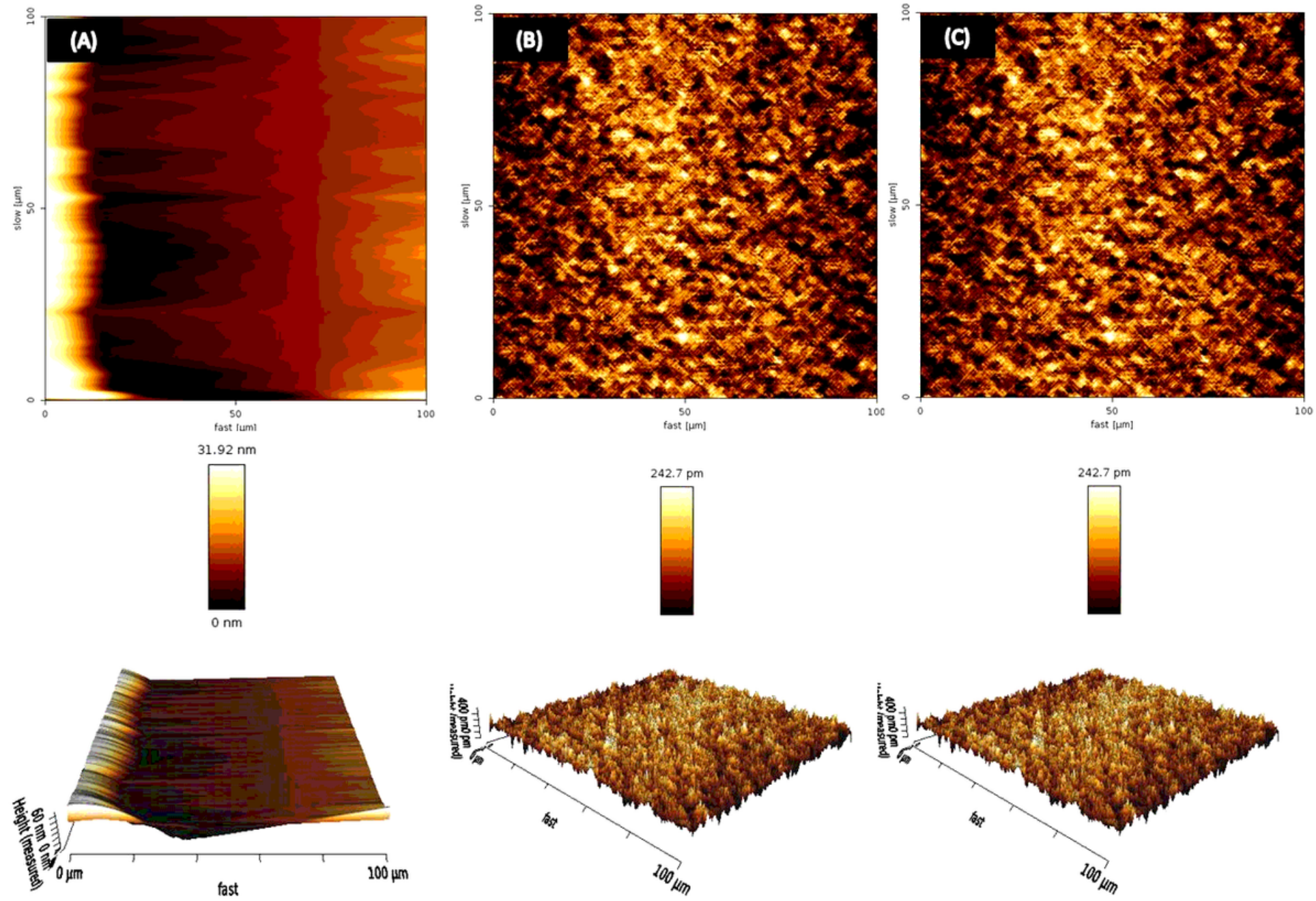

Figure 10

The results of the Atomic Force Microscopy Analysis. (A)NON-IMC (Ra=63.94 pm), (B) EUE-IMC (Ra=70.80PM), and (C) GTE-IMC $(\mathrm{Ra}=70.30 \mathrm{pm})$. ( Scanning range $100 \times 100$ ) 

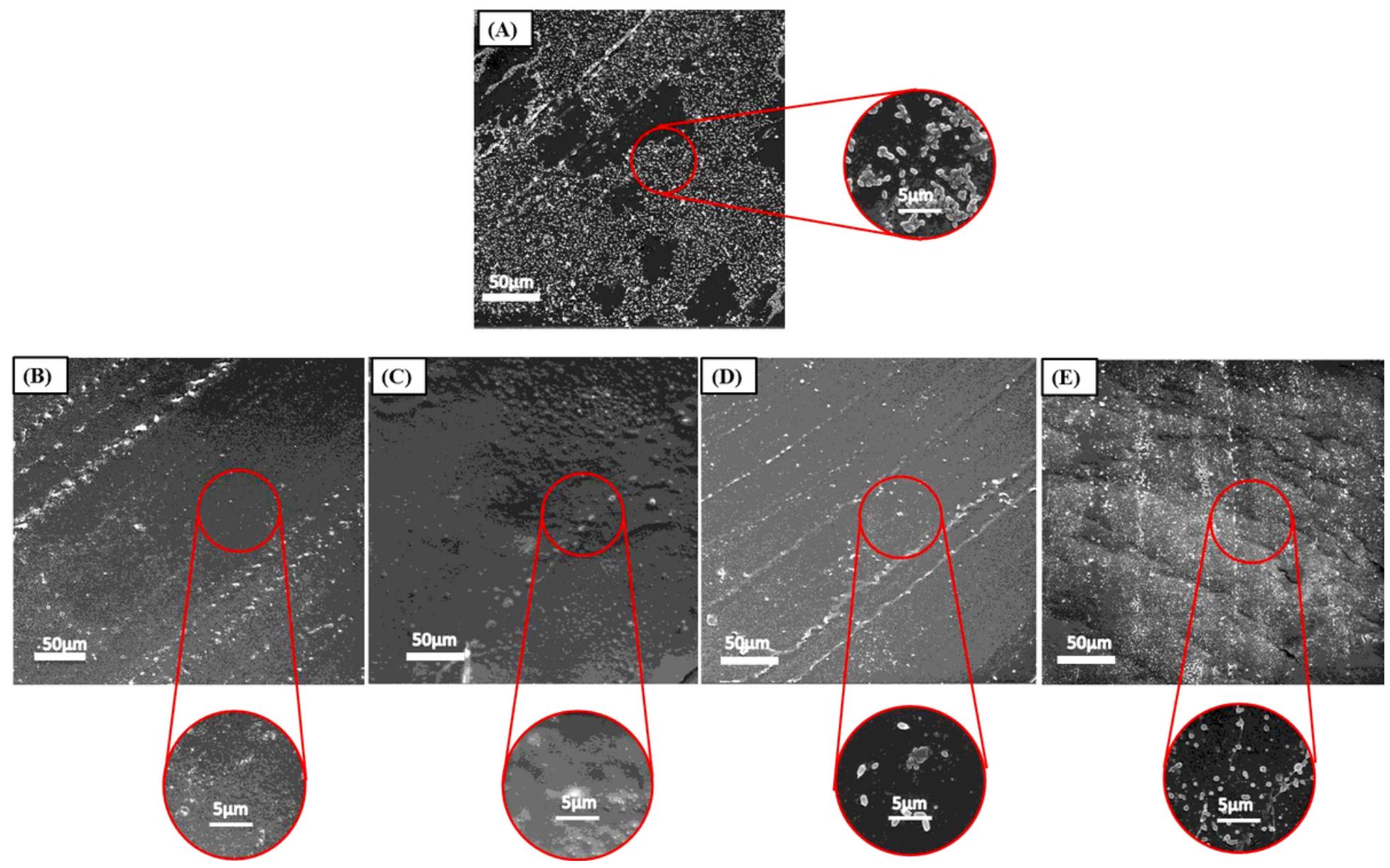

Figure 11

S.aureus bacteria sticking to the surface of the catheters; (A) NON-IMC, (B) EUE-IMC, (C) ROE-IMC, (D) GTE-IMC, and (E) ZIE-IMC. (5, $50 \mu \mathrm{m})$

\section{Supplementary Files}

This is a list of supplementary files associated with this preprint. Click to download.

- GraphicalAbstract.png 